\title{
Flexibility and Sharīah Compliance of Islamic Financial Contracts: An Evaluative Framework
}

\author{
Tareq Moqbel \\ Lecturer in Law, Westminster Law School, University of Westminster, \\ London, UK \\ t.moqbel@westminster.ac.uk \\ Habib Ahmed \\ Professor and Sharjah Chair in Islamic Law \& Finance, Durham University \\ Business School, Durham University, Durham, UK \\ habib.ahmed@durham.ac.uk
}

\begin{abstract}
Although the key distinguishing feature of Islamic finance is compliance with Sharīah, there is criticism from various quarters on the Sharīah compliance of its products. However, there is no objective way to assess the Sharī'ah compliance of Islamic financial contracts. This article develops a structured framework for analysing Sharīah compliance of Islamic financial contracts by deconstructing them and developing principles of evaluation based on concepts from Islamic legal theory. Other than providing a framework to assess Sharī'ah compliance of Islamic financial contracts, this article also alludes to an important issue regarding the contracts' flexibility. Using concepts from Islamic legal theory, the article classifies different contractual stipulations according to their legal weight, and identifies how legal perspectives on the requirements of compliance can determine the flexibility of contracts. An evaluative framework is used to assess the Sharīah compliance of an actual mudârabah (silent partnership) contract and finds it to be defective.
\end{abstract}

\section{Keywords}

Islamic finance - Sharīah compliance - Islamic legal theory - flexibility of contracts mud̄ārabah 


\section{Introduction}

Islamic banking was initiated in 1975 primarily to meet the financial needs of Muslims who preferred not to deal with interest due to religious convictions. During its short history, the industry has expanded rapidly to become a significant sector globally. Compliance with Islamic law (Sharīah) is what defines the 'Islamic' nature and is the justification for the existence of Islamic finance. ${ }^{1}$ Sharīah compliance is ensured by Sharīah supervisory committees/ boards who certify conformation of all financial products and contracts with Islamic law. ${ }^{2}$ The practice of Islamic finance, however, has been criticised for failing to fulfil certain Sharīah requirements. The contention is that Islamic finance is mimicking its conventional counterparts too closely and in the process diluting Sharīah principles. ${ }^{3}$ For example, El-Gamal claims that Islamic financial institutions are rent-seeking Sharî‘ah arbitrageurs using stratagems to circumvent prohibitions of Islamic law. ${ }^{4}$ Some Shari`ah scholars have also pointed out problems with the contractual framework used in Islamic financial products. Usmani asserts that the majority of șukūk (Islamic bonds) replicate conventional bonds, and are not in line with the spirit of Islamic law. ${ }^{5}$ Similarly, Delorenzo is critical of the Islamic total return swap and declares it to be unacceptable from a Sharīah point of view. ${ }^{6}$ The above concerns raise

1 A. Diaw \& I. Febianto, 'Sharīah Report: A Potential Tool for Sharīah Non-Compliant Risk Management', in H. Ahmed, M. Asutay \& R. Wilson (eds.), Islamic Banking and Financial Crisis: Reputation, Stability and Risks (Edinburgh: Edinburgh University Press, 2014); H. Ahmed, 'Shari'ah Governance Regimes for Islamic Finance: Types and Appraisal', International Economics 64(4) (2011): 393-412.

2 W. Grais \& M. Pellegrini, 'Corporate Governance and Stakeholders' Financial Interest in institutions Offering Islamic Financial Services', World Bank Policy Research Working Paper No. 4053, November 2006, online at: https://elibrary.worldbank.org/doi/pdf/10.1596/1813 -9450-4053, accessed 27 May 2020; R. Hayat, F. Den Butter, \& U. Kock, 'Halal Certification for Financial Products: A Transaction Cost Perspective', Journal of Business Ethics 117(3) (2013): 6o1-613.

3 For a critical view on the practice of Islamic finance, see A. Dusuki \& A. Abozaid, 'A Critical Appraisal on the Challenges of Realizing Maqāșid al-Sharīah in Islamic Banking and Finance', IIUM Journal of Economics and Management 15(2) (2007): 143-165; and M. El-Gamal, Islamic Finance: Law, Economics, and Practice (Cambridge: Cambridge University Press, 2006).

4 El-Gamal, ibid., pp. xi, 165, 190-191.

5 M.T. Usmani, 'Sukuk and Their Contemporary Applications', online at: http://alqalam.org.uk/ wp-content/uploads/2017/o7/Mufti-Taqi-sukuk-paper.pdf, p. 13, accessed 27 May 2020.

6 Y. DeLorenzo, 'The Total Returns Swap and the "Shari'ah Conversion Technology" Stratagem', in C. Beard (ed.), Conventional? The Relationship Between Islamic Finance and the Financial Mainstream (London: Arab Financial Forum, 2008). 
an existential question for Islamic finance: What makes a contract Sharīah compliant?

Structuring Islamic financial products requires not only adapting the classical Islamic nominate contracts to the new financial structures, but also adding additional conditions that are not present in traditional contracts. Using traditional contracts and adding new features in financial products raise a pertinent question on Sharīah compliance: to what extent should the clauses/ stipulations of classical contracts be fulfilled when structuring a Sharīah compliant financial product? The answer to this question depends on the flexibility of classical contracts and the extent to which these can be used in contemporary times. Addressing this question would require deconstructing a contract to evaluate its individual conditions/stipulations in terms of their essentiality and legal weight. While violating an essential condition that is considered a key pillar will make a contract defective, a breach of a stipulation that is not essential will not. The classification of contractual clauses according to their legal weights necessitates developing a framework to assess the legal weight of each stipulation from the Sharīah perspective by using principles from Islamic legal theory.

The aim of this article is to develop a structured framework for analysing the Sharīah compliance of Islamic financial contracts. This is achieved by deconstructing a particular contract and developing principles of evaluating contractual stipulations using concepts from Islamic legal theory. Assessing Sharīah compliance, however, would first require identifying a benchmark against which actual contracts used by the Islamic finance industry can be evaluated. This article adopts the AAOIFI Sharīah Standards $(2015)^{7}$ as a benchmark as these standards are developed specifically for the Islamic financial industry and are apparently credible as they are approved by an international Sharīah Board representing esteemed Sharīah scholars from different parts of the world, and of different schools of Islamic law. This article then uses principles from Islamic legal methodology (ușül al-figh) to suggest a framework to appraise the stipulations required by the AAOIFI Standards, and organises them into a hierarchical order of legal strength and legitimacy. This framework, which classifies the different contractual stipulations of the AAOIFI Sharīah Standards in terms of their legal weight, is then used to assess the Sharíah compliance of one real-life contract as a test case.

The article is divided as follows. Following the Introduction, Section 2 discusses methodological approaches related to Islamic law in general and

7 The Accounting and Auditing Organization for Islamic Financial Institutions (AAOIFI), Shariah Standards (Manama: AAOIFI, 2015). 
Sharīah compliance of contracts in particular. Section 3 presents a methodological framework for examining Sharīah compliance. The developed framework is then applied to assess one real-life mudārabah (profit-loss sharing) contract - the case study—in Section 4 . Section 5 concludes with a summary the main remarks.

\section{Islamic Contracts and Sharīah Compliance: Methodological Foundations}

As the scope of coverage of contracts under Islamic law is wide, elements of a general theory of contracts exist in Islamic legal literature. ${ }^{8}$ In general, a contract ('aqd) is an agreement between two persons in a legally binding and impactful manner. ${ }^{9}$ Sharīah regards contracts as a cause which creates a legal effect. ${ }^{10}$ Islamic commercial law (figh al-mu'ämalät) defines and specifies detailed rules of several nominate contracts that serve as a foundation for all transactions. ${ }^{11}$ The pre-designed nominate contracts can be classified into three types. ${ }^{12}$ First, contracts of exchange, which are those in which parties exchange goods/services for a payment or consideration. The types of contracts in this category include sale (bay) and hire (ijärah) contracts. Second, accessory contracts. These are contracts in which one party assigns work/capital/obligations to other parties. Accessory contracts include agency (wakälah), partnership (sharikah) and pledge or mortgage (rahn). Finally, gratuitous contracts transfer ownership or possession (rights of use) without consideration; payment or compensation. These are considered benevolent acts. The main contracts under this category are the loan ('äriyyah and qard), deposit (wadīah), gift (hibah) and guarantee and personal security (damān and kafālah).

8 See J. Schacht, An Introduction to Islamic Law (Oxford: Clarendon Press, 1982); N.J. Coulson, Commercial Law in the Gulf States: The Islamic Legal Tradition (London: Graham \& Trotman, 1984); 'A. El-Hassan, 'Freedom of Contract, The Doctrine of Frustration, and Sanctity of Contracts in Sudan Law and Islamic Law', Arab Law Quarterly 1(1) (1985):51-59; M. al-Zarqā, al-Madkhal al-Fiqhī al-Āmmm Ikhrāj Jadīd, Vol. 1 (Damascus: Dār al-Qalam, 2004), pp. 377-647.

9 A. Kharoufa, Transactions in Islamic Law (Kuala Lumpur: A.S. Noordeeen, 200o).

10 M. Kamali, Islamic Commercial Law: An Introduction (Oxford: Oneworld Publications, 2000).

11 Y. DeLorenzo, 'The Religious Foundations of Islamic Finance', Jurist 6o (2000): 137-161; F. Vogel \& S. Hayes, Islamic Law and Finance: Religion, Risk, and Return (Boston: Kluwer Law International, 1998).

12 See, for a discussion on the different types of Islamic contracts, Vogel \& Hayes, ibid.; S.E. Rayner, The Theory of Contracts in Islamic Law (London: Graham and Trotman, 1991). 
Hassan argues that the general principle of commutative justice governs exchange contracts and liberality underlays gratuitous contracts. ${ }^{13}$ To ensure commutative justice in nominate contracts, Islamic law introduces terms and conditions that must be fulfilled. Individual nominate contracts have detailed conditions that are meant to avoid discord and protect the rights of the parties. Specifically, there are various rules governing the formation of a contract (intention, consent, competence of the parties, and subject matter of the contract), termination of the contract, and the transfer of obligations. ${ }^{14}$ To be valid from a legal perspective, a contract must fulfil certain fundamental requirements and subsidiary conditions. ${ }^{15}$ For example, conditions of the sale contract include those relating to parties to the contract (buyer and seller), object of the contract (price and what is priced), and language of the contract (offer and acceptance). ${ }^{16}$

Understanding the nature and status of the stipulations of various nominate contracts would require examining their standing from a legal methodological perspective which is presented next.

\subsection{Methodological Approaches}

The sources of Islamic legal principles and values can be broadly classified into two: revealed and derived. The revealed knowledge, the Sharīah, constitutes the primary source of Islamic law. ${ }^{17}$ Shari`ah can be further divided into the recited revelation (the Qurān) and the non-recited revelation (the Sunnah). ${ }^{18}$ Whereas the Qurān is the revelation from Allāh to the Prophet Muhammad, the Sunnah constitutes the Prophet's sayings, doings, and tacit approvals. The second source of knowledge is derived from human intellect through ijtihäd

13 H. Hassan, 'Contract in Islamic Law: The Principles of Commutative Justice and Liberality', Journal of Islamic Studies, 13(3) (2002): 257-297.

14 A. al-Rawi, 'Principles of the Islamic Law on Contracts', George Washington Law Review 22(1) (1953): 32-39.

15 Al-Zuhaylī discusses various subsidiary conditions identified by different schools. For example, the Hanafis point out additional stipulations of a valid sale. These include conditions of conclusion, validity, execution and bindingness. See: W. al-Zuhaylī, Financial Transactions in Islamic Jurisprudence, Vol. 1, M. El-Gamal (trans.) (Beirut: Dār al-Fiqh al-Mucāșir, 2003).

16 Al-Zuhaylī, ibid.

17 In this article, Sharīáah denotes the laws based on scriptural texts (Qurān and Sunnah). For a discussion, see H.H. Hassan, 'The jurisprudence of financial transactions [ figh al-mu'āmalāt]', in A. Ahmed \& K.R. Awan (eds.), Lectures in Islamic Economics (Jeddah: Islamic Development Bank, 1992).

18 T.J. al-Alwani, Source Methodology in Islamic Jurisprudence: Usul al-Figh al-Islami (Herndon: The International Institute of Islamic Thought, 199o). 
(exertion). Ijtihād is a process of independent reasoning by qualified scholars to develop legal rules that reflect the essence and spirit of Sharīah. Both sources, revealed and derived, are nevertheless intertwined. The formation of Islamic jurisprudence ( $f i g h$ ) was initiated by individual jurists in the later part of the $7^{\text {th }}$ century. The introduction of figh led to a diversity of the legal opinions that crystallised mainly into four major jurisprudential schools of thought in the Sunni tradition..$^{19}$ The four Sunni schools, named after the pioneering scholars, are the Ḥanafī, Mālikī, Shāfíi and Ḥanbalī. This is in addition to the Shīî schools of law, such as the Imāmiyyah.

The key concern in ijtihäd is to link the new rulings to Sharī'ah. Islamic legal theory (ușull al-figh) provides various sources and methods to derive the substantive law. ${ }^{20}$ Other than depending on the primary sources of law, the Qurān and Sunnah, ușül al-figh identifies other sources that can be broadly classified as secondary and tertiary. The secondary sources of Islamic law include $\ddot{i j m} \bar{a}^{c}$ (consensus) and qiyās (analogy). While $\ddot{i j m} \bar{a}^{c}$ (consensus) is the unanimous agreement of scholars of the Muslim community, qiyās (analogy) is a method to deduce laws which requires identifying and discovering the goals and objectives of the Law-Giver and involves human intellect and evaluation. The tertiary sources of law include additional methodological tools such as istihsān (juristic preference), mașlahah mursalah (unrestricted interest), sadd adh-dharä $i^{\prime}$ (blocking the means), 'urf (custom), and istișhāb (presumption of continuity). One difference between the secondary and tertiary sources is that while almost all jurisprudential schools accept the former as legitimate sources of law, there is disagreement among them on the use of the latter methods. For example, while the Hanafi school would consider istihsān to be a valid method, and the Mālikìs use the notion of a mașlahah mursalah, the Shāfi'is do not, generally speaking, accept these as valid. ${ }^{21}$

The notion of al-hukm at-taklift, which classifies acts into five types (al-ahkām al-khamsah), is key to understanding the framework of law and morality in Islamic legal thought. According to al-ậkäm al-khamsah, any act

19 The other major division being the Shīī tradition. For a discussion on the evolution of jurisprudential schools, see Coulson, supra note 8; and W. Hallaq, A History of Islamic Legal Theories: An Introduction to Sunnī Ușūl al-Fiqh (New York: Cambridge University Press, 1997).

20 A discussion on the Islamic legal methodologies is found in Hallaq ibid; A. Kharoufa, Philosophy of Islamic Sharia and its Contribution to the Science of Contemporary Law (Jeddah: Islamic Development Bank, 200o); M.A. Laldin, Introduction to Shariah and Islamic Jurisprudence (Kuala Lumpur: Cert Publications, 2006).

21 M. Izzi Dien, Islamic Law: From Historical Foundations to Contemporary Practice (Notre Dame: University of Notre Dame Press, 2004); N. Saleh, 'The Law Governing Contracts in Arabia', International and Comparative Law Quarterly 38(4) (1989): 761-787. 
can be classified into one of the following: obligatory (wäjib or fard), recommended (mandūb), permissible (mubāh ), reprehensible (makrūh) and forbidden (muharram) ${ }^{22}$ It should be noted that one of the jurisprudential schools, the Ḥanafì school, distinguishes between al-makrūh tanzīhan and al-makrūh tahriman. The latter is considered akin to the muharram and, thus, must be avoided. ${ }^{23}$ Kamali contends that while the first and last types of acts ( $w a \bar{j} i b$ and muharram) have legal force, the recommended (mandüb) and reprehensible (makrūh) fall in the domain of morals. ${ }^{24}$ The permissible (mubāh $)$ is neutral, with no legal and moral connotations. Thus, whereas stipulations that fall under the obligatory and the prohibited will have the disposition of legality, the recommended, reprehensible and the permissible can be considered as non-legal conditions. ${ }^{25}$

The discussion on the methodological approaches presented above provides the basis of a framework that can be developed to assess Sharí'ah compliance of different contracts. First, from the classifications of al-hukm at-takliffi, the stipulations of any contract need to be first categorised into legal and nonlegal components. In particular, the clauses that fall under the obligations (wäjibāt) and prohibitions (muharramāt) are considered legal requirements, whereas the recommended (mandüb), reprehensible (makrüh) and the permissible (mubăh) can be considered as non-legal conditions. The legal conditions of a contract can be understood as affirmative (wājibāat) and prohibitive (muharramāt), with the former being obligatory commissions and the latter constituting the forbidden stipulations. Examples of the affirmative conditions of a sale contract include the requirement that parties to a contract must be sane, and that the object of sale must be deliverable.

Prohibitions in economic transactions can be broadly classified into riba and gharar. ${ }^{26}$ Rib $\bar{a}$ (literally meaning an increase or growth) is prohibited by Sharī'ah. Although it is common to associate ribā with interest, it has much

22 Al-Zuhaylī, supra note 15; F.S. Carney, 'Some aspects of Islamic ethics', Journal of Religion 63(2) (1983): 159-174; A.K. Reinhart, 'Islamic law as Islamic ethics', Journal of Religious Ethics 11(2) (1983): 186-203.

23 See M. Abū Zahrah, Ușūl al-Fiqh (Cairo: Dār al-Fikr al-'Arabī, n.d.), pp. 45-46; A. Khallāf, Ilm Ușūl al-Figh (Cairo: Maktabat ad-Da'wah al-Islāmiyyah, n.d.), p. 114; M.H. Kamali, Principles of Islamic Jurisprudence (Kuala Lumpur: Ilmiah Publishers, 1998), pp. 331-332.

24 M.H. Kamali, Shariah Law: An Introduction (London: Oneworld Publications, 2008).

25 While legal conditions can be adjudicated in courts, non-legal conditions are ethical in nature and cannot be implemented by court systems. In other words, non-compliance with them does not entail any legal violation.

26 While some authors consider gambling (maysir) as an additional prohibition, it can be categorized as a form of gharar. S. al-Suwailem, Hedging in Islamic Finance (Jeddah: Islamic Development Bank, 2006), p. 73, considers gambling as the purest form of gharar. 
wider implications and can take different forms. The common premise in the prohibition of riba lies in the unequal exchange of values. ${ }^{27}$ Whereas gharar literally means 'danger' and also signifies deception, the word has connotations of uncertainty, risk, and hazard. It also implies ignorance, gambling, and fraud. ${ }^{28}$ These prohibitions generate various rules and principles that govern different aspects of contracts, as will be seen below.

Having laid the general theoretical foundation, in the next section we look at the process of contractual analysis.

\section{$2.2 \quad$ Decomposition and Status of Contracts}

Contracts can be analysed at two levels. The first level of analysis relates to the decomposition of contracts, and to assessing the legal weights of the constituent clauses and stipulations; what we can term as the micro-analysis. Once the legal clauses of a contract have been separated from the non-legal ones, the former can be further analysed in terms of their degree of legitimacy by using different sources of usūul al-figh. Whereas the rulings upon which there is consensus are accepted by all schools, the rulings derived from qiyās, analogy, and other sources, constitute points of disagreement among the different schools. Additionally, the rulings derived by using tertiary sources are expected to be more diverse as the methods under this category are not accepted by all schools. The legal conditions can, therefore, be classified in terms of their degree legitimacy depending on their universality and acceptability by different schools. To this end, we suggest a threefold classification. The contractual stipulations upon which there is a consensus $(i j m \bar{a})$ will be considered the most legitimate, followed by the rulings accepted by the majority of scholars. The residual clauses that do not fall under the $\ddot{j} m \bar{a}^{c}$ nor the majority categories, represent the views of a minority of scholars and are, thus, assigned less weight.

It follows that the different evaluative schemes can be devised based on the three-level classification of the contractual stipulations. A strict interpretation would require that all three types of stipulations - those that derive from consensus, majority, and minority views - must be fulfilled. This, seemingly hypothetical, perspective will be advocated by scholars who maintain that

27 M.N. Siddiqi, Riba, Bank Interest and the Rationale of its Prohibition (Jeddah: Islamic Development Bank, 2004).

28 For a detailed discussion on gharar, see: M. El-Gamal, 'An Economic Explication of the Prohibition of Gharar in Classical Islamic Jurisprudence', Islamic Economic Studies 8(2) (2001): 29-58; S. al-Dhareer, Al-Gharar in Contracts and its Effect on Contemporary Transactions (Jeddah: Islamic Development Bank, 1997); Kamali, supra note 10. 
all the conditions must be fulfilled for a contract to be valid. ${ }^{29}$ However, this view makes the contracts inflexible as it entails that new financial products have to comply with all the stipulations. At the other end of the continuum, the liberal view would be to consider only the stipulations on which there is consensus $(i j m \bar{a})$ to be binding, the implication of which is that violations of majority and minority views would not invalidate a contract. This perspective will make contracts more flexible and make Islamic financial contracts more adaptable. Finally, a middle position would be one that requires the fulfilment of $\ddot{j} m \bar{a}^{c}$ and majority rulings for contracts to be valid. The implication is that while noncompliance with minority-based stipulations (that is, stipulations required by a relative minority of jurists) would not void the contract, violation of conditions categorised as $i j m \bar{a}^{c}$-based and majority-based will make a contract invalid. ${ }^{30}$ Note that the perspective taken will determine the flexibility of contracts: the first view deems the contracts inflexible, the second perspective is more accommodating and adaptable, and the third view makes the contracts moderately flexible without sacrificing the key principles.

Note also that the non-legal stipulations, that is, those added in contemporary financial contracts for facilitation and administrative purposes would be considered neutral and acceptable if they do not directly violate any of the legal prohibitions. This is in line with the methodological principle of permissibility (ibāhah) which maintains that everything in economic affairs is, in principle, permitted. ${ }^{31}$ The stipulations that are found in contemporary Islamic financial scholarship, and which do not exist in classical contract law can be classified as belonging to the minority category as, by virtue of their genealogy, they cannot

29 A.H. Buang, Studies in the Islamic Law of Contracts: The Prohibition of Gharar (Kuala Lumpur: International Law Book Series, 200o); El-Hassan, supra note 8.

30 A somewhat similar approach, although in a different context, is taken by Derigs and Marzban in which they identify a number of Sharīa compliance strategies for Sharīah screening of stocks. They distinguish between the best-of-strategy, the consensus ( $i j m \bar{a}^{c}$ ) strategy, the liberal strategy, and the majority strategy. The consensus strategy 'considers asset to be compliant if and only if all basic Sharía strategies consider the respective asset to be compliant'. Under the majority strategy an asset is compliant 'if and only if the majority of the basic Sharía strategies consider this asset to be compliant'. The third strategy is the liberal strategy. According to this strategy, 'an asset is considered to be compliant if at least one basic Sharî $a$ strategy considers the asset to be compliant'. See: U. Derigs \& S. Marzban, 'New Strategies and a New Paradigm For Sharīa-Compliant Portfolio Optimization', Journal of Banking \& Finance 33(6) (2009): 1166-1176.

31 Kamali, supra note 10; and 'A. Abū Ghuddah, Qarārāt wa-Tawșiyāt Nadwāt al-Barakah li-l-Iqtișād al-Islāmī min an-Nadwah al-Ūlā wa-hattā an-Nadwah ath-Thalāthīn (Jeddah, Majmū'at al-Barakah al-Mașrifiyyah, 2010), p. 17. 
be said to belong to the classical $i j m \bar{a}^{c}$ or majority classifications. Rather, they have been suggested by contemporary jurists to cater for the unique particularities of emerging products.

The second level relates to the validity and invalidity of contracts taken as a whole, and could be viewed as a consequence of the first phase-it derives from it. In this connection, contracts are usually classified as valid ('uqūd șahịhahh) and invalid ('uqūd bāțilah). Al-Zuhaylī discusses various conditions identified by different schools that make contracts valid. ${ }^{32} \mathrm{~A}$ valid sale is one that satisfies both the main pillars and the subsidiary conditions of the contract. If one of the pillars and/or conditions is not fulfilled, then the contract is invalid. For instance, a sale may fulfil some pillars of the contract (such as offer and acceptance, existence of the object, etc.), but if the object of the sale illegal, then it invalidates the contract. The Hanafis, however, classify contracts into three types: valid (șahịhah), defective (fäsidah) and void (bāțilah). One issue that distinguishes a defective and invalid sale relates to whether one of the main pillars (arkān) is violated versus the violation of a general characteristic (wasf) of the contract. According to the Hanafis, violation of a was f of the contract makes the contract defective, not void. ${ }^{33}$ In this sense, the situation is not equivalent to one in which there is no contract in the first place; rather, the contract could be rectified if the defective component is removed. ${ }^{34}$

\section{3}

\section{Assessing Sharīah Compliance: A Methodological Framework}

The legal methodologies outlined above provide the basis of an analytical framework for assessing the Sharīah compliance of actual contracts used in the Islamic financial industry. The framework of assessing Sharī'ah compliance of contracts used in the Islamic financial industry entails five steps. To be sure, these steps are an amalgamation of both theoretical work and practical procedures, and are to be considered as a template with the capacity to be generalised. The first step involves identifying a benchmark standard against which the actual contracts can be examined. Secondly, classifying the clauses of the benchmark standard into legal and non-legal components. Third, examining and analysing the legal clauses of the benchmark standard and ranking them

\footnotetext{
32 Al-Zuhaylī, supra note 15 .

33 Ibid.

$34 C f$. the concept of rectification in the English law of contracts. See A. Burrows, $A$ Restatement of the English Law of Contract (Oxford: Oxford University Press, 2016), p. 170.
} 
according to their respective legal weights. The fourth step is to examine the actual contracts, the case study that is being assessed, and to assign compliance statuses to the different contractual clauses relative to those in the benchmark standard. Fifth and finally, developing criteria that can be used to assess the different clauses, and hence enable us to issue an overall judgment on the Sharīah compliance of the contract(s) in question. These components of the Sharīah compliance evaluation framework are discussed in detail below.

\subsection{Identifying a Benchmark}

Since there exists a diversity of opinions on the legal requirements of different contracts, assessing Sharīah compliance would first require us to identify a benchmark against which the contracts used in the industry can be compared. The benchmark will ensure consistency and act as a reference point against which actual Islamic financial contracts can be examined.

\subsection{Classifying Stipulations of the Benchmark Contract}

As indicated above, the material of the benchmark contract can be distinguished into legal requirements and non-legal conditions. Omissions or violations of the latter do not affect the validity of a contract; they are out of question. Classifying the standard into these two broad categories is useful for analysing the Sharīah rulings since it eliminates the non-relevant components. The non-legal stipulations include the definitions given in the standard, the explanations and elaborations, as well as the permissible clauses stating that it is permissible to do a specific action or undertake a specific measure in a contract. These permissible items are legally neutral in the sense that the Sharīah does not require them, nor are they sanctioned, that is, prohibited. Specifically, neither do the benchmark Sharīah standards require these stipulations to be present nor do they entail anything that contradicts the standards. In other words, these fall under the mubăh (permissible) category of al-hukm at-taklifit. In line with the notions of obligation (al-wujüb) and prohibition (at-tahrim) under al-hukm at-takliff discussed above, the legal requirements are a combination of affirmative and prohibitive conditions.

On this basis, a general checklist entailing the relevant legal rulings from the benchmark standard is first developed for the contract investigated; in our case the mudārabah. This checklist serves as the main tool in examining the contract. Note that the number of rulings varies from one contract to another reflecting their differing nature. The number of rulings required for a contract is not an indication of its relative importance, but instead demonstrates that some contracts have more complex characteristics than others and are thus subject to increased legal control. 


\subsection{Deconstructing Benchmark Contracts and Ranking Individual Clauses}

Once the legal conditions have been identified, further classifications can be made with regards to their legal weight or degree of legitimacy. As indicated in the methodology devised above, the legal stipulations of a contract can be arranged into a hierarchical order of legitimacy. As indicated, the legal conditions can be ranked into three levels with respect to their legal weight: those that are based on consensus $(i j m \bar{a})$, those accepted by the majority of schools, and those that are maintained by a minority of scholars, where our definition of minority is a broad one - a minority is a view that simply falls short of a majority. This classification requires identifying the stipulations as $\ddot{y} m \bar{a}^{\mathrm{c}}$-based,

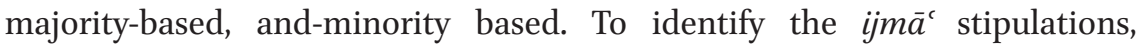
al-Wa'lān's work on consensus in the Islamic law of financial transactions was mainly consulted..$^{35}$ It is a compendium which collates the consensuses across the various topics of the Islamic law financial transactions. Similarly, Sāîs's Mawsūàt Masāill al-Jumhūr fì al-Figh al-Islāmì (Encyclopaedia of the Majority Rulings in Islamic Law) is used as a reference for majority-based rulings. This book is a collection of the rulings - to the knowledge of its author-that are attributed to the majority (al-jumhür) of scholars of Islamic law. ${ }^{36}$

As for the new clauses advanced in contemporary Islamic contractual law, which are naturally not present in traditional nominate contracts, they are assigned to the minority category. Since the new conditions do not belong to the former two groups, they are given the status of minority rulings in terms of the hierarchy of legitimacy.

\subsection{Content Analysis of Case Contract and Compliance Scheme}

The fourth component of the assessment framework consists of evaluating the clauses of the actual contract under assessment. Content and textual analysis of the stipulations of the contract are carried out and compared with those of benchmark. To ensure the objectivity of the procedure as much as possible, it is necessary to read the whole contract, from beginning to end, to arrive at meanings in their proper context. The only units for interpretation are the written words in the contract; the un-communicated intentions that might have been intended by the drafters of the contract are not taken into consideration. This

35 F. al-Wa'lān, Masāill al-Ijmā' fì al-Muharramāt al-Māliyyah wa-'Uqūd al-Mudāyanāt wa-t-Tawthīqāt wa-l-Iṭtāqāt wa-t-Taqyìdāt wa-l-Mushārakāt (Riyadh: Dār al-Faḍīlah, 2014).

36 M. Sāì̄, Mawsūáat Masāill al-Jumhūr fì al-Fiqh al-Islāmì (Egypt: Dār as-Salām, 2005). 
is because intentions that are not expressed in the instrument, in this case the contract, cannot generally bind the other party. However, reference to materials extrinsic to a written document is justifiable in contractual interpretation. ${ }^{37}$ Therefore, to have a better indication and to be fair in judging the Sharīah compliance, process diagrams and other internal supporting documents related to the contracts can be consulted, if available.

In addition to the content analysis, the development of a compliance scheme is an integral component of the contract examination. Due to the lack of studies on the Sharīah compliance of contracts, the scoring scheme used in the literature on the disclosure of annual reports, as well as the studies on the compliance of Islamic banks with the accounting standards, can be used. In particular, the work on the compliance of banks with the AAOIFI reporting standards is useful in this context. ${ }^{38}$

One strand in the literature on annual report disclosure typically applies a dichotomous scoring system whereby an item scores one if communicated or disclosed, and zero if not communicated. ${ }^{39}$ Another strand in the literature follows a three-category approach: a clearly disclosed item scores one (1.0), an ambiguously disclosed item scores one-half (o.5), and an undisclosed item scores zero (0.0). ${ }^{40}$ Without using the numerical values, our model follows the threefold approach and adds two more additional categories; namely, direct contradiction and partial contradiction. Therefore, each clause of the contract is assigned one of the following five categories of statuses in the evaluation scheme:

37 M. Kirby, 'Towards a Grand Theory of Interpretation: The Case of Statutes and Contracts', Statute Law Review 24(2) (2003): 95-111.

38 For example, T. Vinnicombe, 'AAOIFI Reporting Standards: Measuring Compliance', Advances in Accounting 26(1) (2010): 55-65; and T. Vinnicombe, 'A Study of Compliance with AAOIFI Accounting Standards by Islamic Banks in Bahrain', Journal of Islamic Accounting and Business Research 3(2) (2012): 78-98.

39 R. Haniffa \& M. Hudaib, 'Exploring the Ethical Identity of Islamic Banks via Communication in Annual Reports', Journal of Business Ethics 76 (2007): 97-116; R. Haniffa \& T. Cooke, 'Culture, Corporate Governance and Disclosure in Malaysian Corporations', Abacus 38(3) (2002): 317-349.

40 B. Maali, P. Casson \& C. Napier, 'Social Reporting by Islamic Banks', Abacus 42(2) (2006): 266-289; Vinnicombe, supra note 38; B. Inchausti, 'The Influence of Company Characteristics and Accounting Regulation on Information Disclosed by Spanish Firms', European Accounting Review 6(1) (1997): 45-68. 
CS (clearly stated): The benchmark clause is clearly stated in the case contract;

AS (ambiguously stated): The benchmark clause is stated unclearly or ambiguously;

OM (omitted): The benchmark clause is omitted or not disclosed;

IC (implicit contradiction): The benchmark clause is contradicted partially in the case contract; and

EC (explicit contradiction): The benchmark clause is directly and explicitly contradicted in the case contract.

While the CS status, if uniformly satisfied across all stipulations, betokens the likely validity of the contract, the other types of statuses would dilute the Sharīah compatibility of the contract. Importantly however, the implications of the statuses of different clauses on the Sharīah compliance of a contract will depend on the legal weights of the clauses outlined in the previous section.

\subsection{Assessment Scheme and Legal Judgment}

The fifth step, in the development of the assessment scheme, is to devise criteria to issue legal judgments - a verdict regarding the overall validity of a contract. After deconstructing the contract into its constituent clauses, each clause would be assessed in two ways. First, we identify the ranking of the clauses according to legal weights (i.e., $\ddot{j} m \bar{a}^{c}$, majority and minority), as explained in the third step. Secondly, we assess the statuses of each clause with respect to the benchmark standard (in terms of CS, AS, OM, IC and EC, as identified above in the fourth step). We integrate these two steps to assess Sharīah compliance status of a contract.

The criteria used for analysing the Sharīah compliance of the contracts is presented in Table 1. Borrowing from the Hanafi jurisprudential tradition, we use three types of legal decisions or judgments (valid, defective and invalid) to evaluate contractual clauses. Whereas direct violations of the consensusbased affirmative/prohibitive legal rulings, and omissions of such clauses, deem a contract void, an implicit contradiction, or stating ambiguously a required ijm $\bar{a}$ c clause renders a contract defective - a less serious legal breach. Furthermore, an explicit contradiction or an omission of a majority-based clause, will equally make a contract defective. All other cases of noncompliance with regards to majority and minority clauses are not considered serious from our legal weight perspective, and hence do not affect the validity of a contract. 
TABLE 1 Ranking-status matrix of contractual clauses and legal judgment

\begin{tabular}{|c|c|c|c|}
\hline Ranking-Status & $\begin{array}{l}\operatorname{Ijm} \bar{a}^{\mathrm{c}} \\
(\mathrm{IJ})\end{array}$ & $\begin{array}{l}\text { Majority } \\
(\mathrm{MJ})\end{array}$ & $\begin{array}{l}\text { Minority } \\
(\mathrm{MN})\end{array}$ \\
\hline Clearly Stated (CS) & Valid & Valid & Valid \\
\hline Ambiguously Stated (AS) & Defective & Valid & Valid \\
\hline $\operatorname{Omitted}(\mathrm{OM})$ & Void & Defective & Valid \\
\hline Implicit Contradiction (IC) & Defective & Valid & Valid \\
\hline Explicit Contradiction (EC) & Void & Defective & Valid \\
\hline
\end{tabular}

To reiterate, the criteria used to evaluate the requirements of Sharíah compliance of contracts will depend on two factors mainly: the scope of rulings that should be complied with, and the weights attached to the rulings. Whereas the strict view holds that all stipulations should be complied with, the liberal perspective would require compliance with the $\ddot{j} m \bar{a}^{c}$-based rulings only. Our assessment framework uses an intermediate perspective that makes contracts valid with violations or non-compliance of clauses that are minority-based, and also with most of the majority-based clauses.

\section{Sharīah Compliance Assessment: Muḍārabah Contract as a Case Study}

We now turn to our case study, a mudārabah contract used to finance clients by Islamic banks. ${ }^{41}$ The case contract, as it will be termed hereafter, was sourced from a leading Sharīah advisory firm which provides other IFIs with guidance regarding the application of Sharīah principles, and legally compatible, innovative and commercially viable solutions. The identity of the financial institution which provided the contract cannot be revealed due to confidentiality requirements. However, a brief description of the selected institution is in place. The team working at this institution includes world-class experts in the field of Islamic finance, prominent lawyers, bankers, capital market and asset management experts, as well as Sharīah scholars, accountants, auditors and trainers. The institution is involved in the development of many important

41 The mudārabah contract corresponds to the sleeping partnership in conventional commercial law. It is a partnership contract in profit in which one party provides capital and the other provides labor and work. 
pioneering Islamic products and instruments in various countries. The selected contract is a template that is used by various Islamic financial institutions.

In line with the methodological framework identified in Section 3, the analysis of our case study, the mudārabah contract, was carried out as follows.

\subsection{Identifying a Benchmark}

After examining the available options, such as Bank Negara's Parameters ${ }^{42}$ the AAOIFI Sharīah Standards were selected to serve as the benchmark. The AAOIFI Sharīah Standards provide different clauses for various genres of contracts and products. The rationale for selecting the standards includes the following. First, these standards are increasingly regarded as the benchmark for the industry. Second, the AAOIFI Standards are developed and approved by a committee of prominent Sharīah scholars from different countries; this makes it universal and gives it authority and credibility. A feature of this global effort is that it represents views of different schools of jurisprudence with no single school dominating. Due to these features, it has appeal to several Islamic financial institutions worldwide, and has been adopted by some institutions as a benchmark that the Islamic financial sector could utilise. ${ }^{43}$

\subsection{Classifying Stipulations of the Benchmark Contract}

We separated the legal from the non-legal clauses of the AAOIFI Sharīah Standard on mudārabah. We then applied our judgment and discretion in filtering the legal rulings and selecting those which we think are most relevant to the contract under study. Thus, we created our Modified AAOIFI Muḍārabah Sharīah Standard.

\subsection{Deconstructing Benchmark Contract and Ranking Individual Clauses}

Next, we assigned each of our Modified AAOIFI Mud̄arrabah Sharīah Standard rulings to one of the three categories: ijm $\bar{a}$, majority and minority. To identify the ijm $\bar{a}^{`}$ category, we relied mainly on one source: Al-Wa'ān's book on consensus in financial transactions. ${ }^{44}$ As for the majority category, we consulted Sāî's, Mawsūàt Masāìl al-Jumhūr fì al-Fiqh al-Islāmī. All remaining rulings were included in the minority category.

42 Bank Negara Malaysia, 'Draft of Shariah Parameter Reference 3: Mudarabah Contract' (2009), available at: https://www.bnm.gov.my/documents/conceptpaper/attachment_ mudarabah_contract.pdf, accessed 27 May 2020.

43 See: AAOIFI, 'Adoption of AAOIFI Standards', available at: https://aaoifi.com/adoption -of-aaoifi-standards/?lang=en, accessed 28 February 2020.

44 Al-Wa'lān, supra note 35. 
At this juncture, it is pertinent to distinguish between two issues: the required components of a contract, and the stipulations attached to a contract. By the former, we mean those elements that are required to be present in a contract for it to be a valid mudārabah contract, whether they are required by all scholars, the majority of them, or only a minority. In their absence, no contract exists, that is, no contractual obligations are created. By the latter, we mean the stipulations that are attached to a contract by the contracting parties themselves, for example, stipulating that the entrepreneur in a mudārabah bears all the risk. These attached stipulations (ash-shurūt al-muqtarinah bi-l'aqd), ${ }^{45}$ may be permitted by all scholars, the majority, or a minority. Put differently, they may amount to a violation of $\ddot{j} m \bar{a} \bar{a}^{c}$, the view of the majority, or that of a minority of scholars. From a different angle, the first issue relates to the formation of a contract, whereas the latter is concerned with the content of a contract, that is, its terms and clauses, though we have to note that these are sometimes intertwined.

In addressing the first issue, the components of a contract, the following rulings of our Modified AAOIFI Mudārabah Sharíah Standard belong to the $\ddot{j} m \bar{a}^{c}$ category, in that there exists an apparent consensus across Islamic law to the effect that they have to be present in a mudārabah contract (the numbers correspond to the numbering of clauses in the AAOIFI Sharíah Standards 2015, and the rulings have been paraphrased):

4.2. Both parties should possess the legal capacity to appoint agents and accept agency.

7.2. The capital of mudārabah should be clearly known to the contracting parties and defined in terms of quality and quantity in a manner that eliminates any possibility of uncertainty or ambiguity.

7.4. For a mudārabah contract to be valid and for the mudārib to be considered as having control over the capital, the mudārib must have free access to the capital.

8.1. It is a requirement that the mechanism for distributing profit must be clearly known in a manner that eliminates uncertainty and any possibility of dispute, and it must be on the basis of an agreed percentage of the profit.

And the following rulings of the Modified AAOIFI Mudāabah Sharî́ah Standard belong to the majority category. This means that, according to the

45 For a discussion, see: M. Shubair, al-Madkhal ilā Fiqh al-Mu'āmalāt al-Māliyyah: al-Māl / al-Milkiyyah / al-'Aqd (Jordan: Dār an-Nafāiss, 2010), pp. 251-266. 
majority of scholars, the previous group of rulings has to be satisfied, in addition to the following:

7.1. The mudārabah capital must be provided in the form of cash (previously gold and silver).

7.3. The capital should be concrete, 'ayn-it is not permitted to use a debt owed by the mudatrib or another party to the capital provider as capital in a muḍarabah contract.

It follows, through the ușülì tool known as as-sabr wa-t-taqsim, that the following rulings belong to the minority category. This is to say that in the view of some scholars, it appears that the previous two sets of AAOIFI rulings have to be adhered to, in addition to what follows:

3.2. The type of mudārabah must be stated.

4.1. The contract formula must be stated. The mudārabah contract may be concluded using terms such as muḍārabah, qirād or mu'ämalah.

We now turn to the second issue, the conditions attached to the contract. According to all scholars, the following conditions, when stipulated by the contracting parties in a mudārabah contract, constitute a Sharīah violation. Note that we are carefully using the phrase 'Shari'ah violation' to indicate that this is a broad category in the sense that such a violation does not necessarily make a contract void — it might be possible to rectify it.

4.4. Stipulating that the mudārib is liable for losses even when he is not negligent or in breach.

8.1. If one of the parties stipulates that he should receive a lump sum of money.

In the view of the majority of scholars, the following stipulation constitutes a Sharı̄'ah violation:

9.3. Stipulating that the capital provider has a right to work with the mudāarib and to be involved in selling and buying activities or supplying and ordering.

It has to be emphasised that this is a significantly reduced and modified version of the AAOIFI Sharīah Standard on mudārabah. We have left out some rulings, such as the ruling stating that if there is no agreement regarding the 
right of the mudārib to receive living expenses from the mudārabah capital, then the mudārib should take living expenses in accordance with custom and reason. This is because such matters, though they attract legal significance, do not have a bearing on the validity of the contract; and our main inquiry here is the validity of the contract.

\subsection{Content Analysis of Case Contract and Compliance Scheme}

Next, the clauses of the case study, an actual Mudärabah contract used to provide financing to a client, were cross examined against our Modified AAOIFI Mudārabah Sharīah Standard. To clarify, this step involved checking whether or not the clauses of the Modified AAOIFI Mudärabah Sharīah Standard were disclosed in the case contract, as well as assessing the nature of this disclosure. Precisely, each clause of the Modified AAOIFI Mudārabah Sharīah Standard was assigned one of five categories: CS, AS, OM, IC and EC, when analysing the case contract. To give one example, if one of the rulings in our Modified AAOIFI Mudārabah Sharīah Standard was clearly stated in the case contract, it was assigned the CS status.

Furthermore, the stipulations were also examined according to their legal weight or degree of legitimacy. Recall that in Step 4.3, we assigned each of the clauses in our Modified AAOIFI Mudārabah Sharīah Standard model a rank: ijm $\bar{a}$, majority and minority. These rankings were also rolled over to the contract under investigation. This is to say that if, for example, a ruling is clearly stated in the case contract and belongs to the $\ddot{j} m \bar{a}^{c}$ category, it will be given a status CS and a rank IJ. The same logic was applied to all the relevant rulings.

The majority of the components our Modified AAOIFI Mudārabah Sharīah Standard have been clearly stated, that is, unequivocally disclosed, in the case contract. This is presented in Table 2.

TABLE 2 Clauses of the case contract - clearly stated

\begin{tabular}{|c|c|c|c|}
\hline $\begin{array}{l}\text { AAOIFI } \\
\text { Reference }\end{array}$ & Ruling & $\begin{array}{l}\text { Legal } \\
\text { weight }\end{array}$ & $\begin{array}{l}\text { Disclosure } \\
\text { status }\end{array}$ \\
\hline 4.2 & Legal capacity & IJ & CS \\
\hline 7.2 & Capital of mudārabah is clearly known & IJ & CS \\
\hline $7 \cdot 4$ & Mudārib is given control over the capital & $\mathrm{IJ}$ & CS \\
\hline 7.1 & Capital in the form of cash & MJ & CS \\
\hline $7 \cdot 3$ & Capital is not a debt & MJ & CS \\
\hline 4.1 & Formula is stated & $\mathrm{MN}$ & $\mathrm{CS}$ \\
\hline 3.2 & Type of mudārabah is stated & $\mathrm{MN}$ & CS \\
\hline
\end{tabular}


TABLE 3 Clauses of the case contract-implicit contradiction

\begin{tabular}{llll}
\hline $\begin{array}{l}\text { AAOIFI } \\
\text { Reference }\end{array}$ & Ruling & $\begin{array}{l}\text { Legal } \\
\text { weight }\end{array}$ & $\begin{array}{l}\text { Disclosure } \\
\text { status }\end{array}$ \\
\hline
\end{tabular}

8.1

Disclosing the profit distribution procedure, IJ I
on the basis of an agreed percentage.

No component of the case contract, according to our Modified AAOIFI Mudārabah Sharĩah Standard, has been ambiguously disclosed, omitted, or explicitly contradicted. However, the terms of some clauses in the case contract implicitly contradict AAOIFI's $i j m \bar{a}^{c}$ Ruling 8.1, as shown in Table 3.

AAOIFI Ruling 8.1, which states that the distribution of profits must be on the basis of an agreed percentage of the profits and not on the basis of a lump sum or a percentage of the capital, has been partially contradicted. No clause in the contract explicitly violates this requirement and, moreover, there are clauses stating that the distribution of profits is on the basis of a percentage of the profits. However, we maintain the position that this requirement has been at least partially, if not completely, contradicted. This is because there are certain clauses implying that the bank should receive a set amount of profit and this resembles the stipulation of a lump sum, and this is a violation of consensus as stated above.

For example, Clause 4.2 of the case contract holds the mudārib responsible for properly executing the mudārabah to achieve the projected results. It runs as follows (with minor modifications in the transliteration): '... the mudatarib shall be fully responsible for properly executing the mudarrabah in order to achieve the financial results projected by it in the Investment Plan'. This can be considered an indirect contradiction to AAOIFI Ruling 8.1 since a mudārib cannot be held responsible for achieving the projected results and profits. He is only responsible for carrying out the mudārabah as is the custom ( urf).

On a clearer note, Clause 8.3 of the case contract, as it were, contradicts the ruling under investigation. It states that:

In respect of any Profit Distribution Date, if the net asset value of the Mudārabah shows that the Mudārabah Profit payable for such period is equal or more than the threshold [...] and Rabb al-Māl [capital provider] share in the Mudāabah Profit [...] in respect of any Profit Distribution Date [...] is more than the Threshold, then Rabb al-Mâl shall be paid 
its share of the profit up to the Threshold and the surplus (the 'Surplus Profit') will be used as a reserve for the purpose of future Mudarrabah Profit distributions and shall be credited into an Mud̄ärabah Profit reserve account (the 'Profit Reserve Account').

Although the aforementioned clause does not directly contradict AAOIFI Ruling 8.1, since it does not stipulate the allocation of a lump sum, this issue can be looked at from a different perspective. That is, the distribution of profit is required to be a percentage of the profit and the word 'profit' here is absolute. According to this clause, however, there is a certain threshold and cap on the profit distribution. Hence, the distribution of profit is not absolute. This does not necessarily violate Shari`ah requirements; on the contrary, some scholars approve it. Nonetheless, it is presented here to help build the whole picture, which turns out to be, as will be shown, essentially not Sharī'ah compliant.

The essential issue in this clause is that in the case where the net asset value of the mudarabah shows that the rabb al-māl entitlement is less than the threshold. Clause 8.3 of the case contract states that:

... if the net asset value of the Mudarrabah shows that the RM [rabb al-māl] Entitlement is less than the Threshold (being the 'Shortfall'), then in respect of any Profit Distribution Date, the amounts standing to the credit of the Profit Reserve Account shall be utilised to meet the Shortfall so that the RM Entitlement is as per the Threshold.

The problem here is that it emphasises the fact that the capital provider, rabb $a l-m \bar{a} l$, is indirectly guaranteed a fixed return - this violates AAOIFI Ruling 8.1 implicitly. In addition, it is apparent that the contract is designed to benefit the rabb al-māl which, in this case, is the financial institution. To make this clear, the clause only refers to a situation in which the rabb al-māl entitlement is less than the threshold and does not make any reference to the mudärib. In other words, there is no clause stating that if the mudarrib's entitlement is below a certain threshold then he is entitled to compensation from the profit equalisation reserve. ${ }^{46}$ This raises issues regarding equality in the contract and its structure that benefits one party over the other, in this case the rabb al-māl (the IFI).

$46 \quad$ It may be argued here that the mudārib does not contribute any money and thus does not face any risk. However, the muda arib's contribution is the labour and it is, in the final analysis, a type of contribution similar to that of the rabb al-māl. 
The issue becomes even more apparent in situations where there are insufficient funds available in the profit reserve account to ensure the payment to the rabb al-mäl as per the threshold. Clause 8.3 of the case contract states that, in this case: '... [the Customer] (in his personal capacity) shall utilise his own funds on an 'on-account basis' to meet the Shortfall'. Thus, according to this clause, the mudārib shall utilise his own funds to meet the shortfall on an 'onaccount' basis, though he might not be negligent. This means that at the end of the mudārabah, any on-account payments paid by the mudāarib shall be repaid back to him.

However, if the mudatrabah funds have been exhausted, or if the mudārabah suffers a total loss and there are no amounts payable to the rabb al-māl, then how will the mudārib be compensated? The contract provides no answer to this issue. Therefore, it can be tentatively concluded that the contract is designed in such a way that the rabb al-mäl is guaranteed a certain amount-and this is similar to stipulating a lump sum. Thus, it appears to be a violation of AAOIFI Ruling 4.4, and Ruling 8.1. In addition, the contract gives an illegitimate advantage to one party over the other. Hence, Clause 8.3 of the case contract mentioned above falls under the partial or implicit contradiction category.

\subsection{Assessment and Legal Judgment}

It has to be noted that although most of the required clauses are clearly stated in the actual contract, one contractual stipulation, Clause 8.3 of the case contract, seems to be in an implicit violation of consensus. Thus, we can conclude that the contract is defective, as suggested in Table 1. But what does defective mean? Is the contract void, or could it be rectified? To clarify, the main problem with the case contract is that it seems to stipulate that the muda arib bears the loss even when he is not in breach. Here we have two classical views: whereas the Hanafĩ school of law, among others, holds that the contract is intact but the stipulation void, others maintain that the whole contract is void. ${ }^{47}$

In addition, the analysis shows that there is a significant issue in the contract examined. It is that the whole transaction is similar, in some ways, to a conventional interest-bearing loan in substance. This stems from the violation of AAOIFI Ruling 8.1, and can be illustrated as follows. The bank is the rabbal-māl and expects a fixed, guaranteed return on the money 'lent' to the mudärib. Ultimately, then, it is as if the rabb al-māl has provided the mudârib with a loan and expects the loan to be returned plus a mark-up. This can potentially 
be considered riba . In substance, all that is accomplished by this transaction is to replicate an interest-bearing loan under the 'Islamic' rubric of mudārabah.

This article uses concepts from Islamic legal theory to develop a framework to assess the Shari`ah compliance of different contracts used in the Islamic financial industry. Although the article develops a framework to assess Sharīah compliance, it also provides insights into the conditions that can make contracts flexible. Legal weights can be assigned to different clauses based on the level of agreement and acceptance of different scholars. Accordingly, clauses can be ranked in three levels of legitimacy: $\ddot{j} m \bar{a} \bar{a}^{c}$, majority and minority. The flexibility of contracts will thus depend on the perspective regarding the requirements a contract ought to fulfil. At one end of the spectrum, a strict perspective would be one in which the violation of any clause (i.e., $\ddot{j} m \bar{a}^{c}$, majority, or minority) would invalidate a contract. At the other end, a liberal perspective would be hold that only an explicit contradiction or an omission of an ijm $\bar{a}$-based ruling will make a contract void. Otherwise, a contract would be valid. Whereas the former view would make contracts rigid and inflexible, the latter makes them accommodating and adaptable.

The framework for assessing the Sharīah compliance of contracts used in the Islamic financial industry requires deconstructing a contract into its constituent clauses and evaluating it using five steps. First, identifying a benchmark standard against which the actual contracts can be compared. Second, classifying the clauses into legal and non-legal components. Third, the clauses with legal dispositions in the benchmark contract are analysed and ranked according to their legal weights. The fourth step is to evaluate the real life contracts that are being assessed and assign compliance statuses to the different contractual clauses relative to the benchmark standard. Finally, the clauses and stipulations in actual contracts are assessed and legal judgments are issued. By developing a framework to assess the flexibility and Sharíah compliance of Islamic financial contracts, the article provides insights into how concepts of Islamic legal methodology can be used to address issues arising in contemporary applications of Islamic law.

As indicated, the practice of Islamic finance has been criticised for diluting the principles of Sharíah. The evaluative framework can be used to provide a reasonable assessment of the Sharīah compliance of Islamic financial contracts applied in the Islamic financial sector. As an example, the article 
uses the evaluative framework to assess the Sharīah compliance of a real life mudatrabah contract. A ranking-status matrix is developed to evaluate the Sharíah compliance of the individual contractual stipulations. The overall analysis of the muda arabah contract, however, shows that it is defective. Though the contract examined is a single case study and cannot be safely generalised, it is indeed consistent with the criticism that Islamic financial practice does not strictly adhere to the expectations of Islamic law. 